\title{
Communication and the Shaping of Human Personality; Deconstructing the Nature/Nurture Debate in Light of the Menace of Street Children in Nigeria
}

\author{
Kizito Ogedi Alakwe*, Silk Ugwu Ogbu
}

School of Media and Communication, Pan-Atlantic University, Lagos, Nigeria

* Corresponding author email: kizito.alakwe@pau.edu.ng

Received: 15 March 2018 / Revised: 31 March 2018 / Accepted: 16 April 2018 / Published: 30 April 2018

\begin{abstract}
At the core of the knowledge inquiry about behavioural differences is the nature versus nurture debate which has been central to the development of various theories of human personality. The metaphor of a pendulum, swinging back and forth between nature and nurture, has been used to depict the opinion of scholars and practitioners in the social sciences and psychology in this debate. Nature / Nurture debate seeks to proffer answers to the following questions: why do people differ significantly in temperament, approach to challenges and level of intelligence even when they are siblings sharing from the same pool of genes? The debate also seeks to understand why people with different genetic trait behave alike within a group. How does our physical environment affect human behaviour and what role does communication play in the development of human personality? In the context of street children in Nigeria, should we attribute human personality to nature or nurture? These are issues this paper seeks to deconstruct. Methodologically, the paper examines critical theories of human personality and utilises a mix of review of relevant literature, comments and observations to discuss the role of communication in the formation of human personality. It concludes that though nature contributes towards human behaviour and personality, communication, which is the tool that drives socialisation, is central to the development of personality among the street children of Calabar. Thus, if communication can influence personality negatively, then the street children of Calabar have a chance of being rehabilitated through a different kind of communication aimed at behaviour modification.
\end{abstract}

Keywords: Human Personality; Nature-Nurture Debate; Street Children; Behaviourism; Skolombo Boys; Juvenile Rehabilitation; Lacassera Girls

\section{Introduction}

One major challenge facing many third world nations is the lack of a thriving, youthful population empowered to contribute to the growth and development of their economies. Scholars, multilateral agencies, and non-governmental organisations attribute this to lack of proper training, requisite education and guidance in the formative years of these youths. According to a report published by UNICEF in 2015, about 10.5 million Nigerian children between the ages of 5 and 18 are not in school with $60 \%$ of this number from the Northern part of Nigeria. The societal consequence of this report is the astronomical rate of illiteracy, the current rise in violent crimes committed by children across the Nigerian states, and the considerable cost associated with prosecuting or reforming these juveniles (UNICEF, 2015; BBC, 2017). Many of these out of school children fall into the category of what is referred to as "Street children". These are children that have been abandoned, rejected and ostracised by parents, guardians and the society in general and are found roaming the streets as a result of circumstances beyond their comprehension and control (Usang, Okpechi, \& Ekpo, 2016).

All over Nigeria, these children paint a picture of hopelessness and helplessness as they have been cut-off from all family and societal ties. Having been abandoned by family, the government, and society in general, these children had all but lost hope for survival. They roam the streets night and day seeking for their next 
Communication and the Shaping of Human Personality

meal and are willing to do anything that guarantees their daily survival on the streets. They make the bridges, motor parks, refuse dumps and the most dangerous parts of the city their home and retire to these places at night after a day of foraging for food all over the city. To survive, they engage in street begging, manual labour, and petty crimes on a day-to-day basis and sometimes search for crumbs from domestic waste bins and refuse dumps. The older ones among them find it hard to adjust to this lack of individuality and belongingness while the younger ones crave for parental love and care. This leads to extreme depression and suicidal tendencies, which leaves an indelible scar in their persona for as long as they survive the streets. The girls among them are subjected to all sorts of sexual abuse and most times end up as prostitutes. The increasing number of these children on Nigerian streets is a source of concern not only to the government but also to the entire country. With more children being abandoned and neglected, the end to this phenomenon cannot be said to be in sight. One of such groups of street children in Nigeria is the Skolombo Boys of Calabar, a city in the South-South region of Nigeria.

The name Skolombo originated from a Jamaican slang "Skolo" which means "to obtain" (Ibanga, 2016). The group comprises children and teenagers of between 5 and 18 years old. Numbering in their hundreds, these children take refuge in the marketplaces, motor parks, unoccupied public buildings and uncompleted buildings. The girls among them were called "Lacassera Girls" after a favourite soft drink in Nigeria on the understanding that all it takes for the girls to engage in a sexual act is just one bottle of this soft drink (PIND, 2017). To survive, these children engage in all sorts of criminal activities: pickpocketing, burglary, prostitution, armed robbery, and murder. Their presence in the streets has been attributed to many factors. Chief among these factors is witchcraft (Akpan, 2015; Umukoro, 2016). That some families in the SouthSouth city of Calabar still believes firmly in witchcraft is an indication of the low level of education and enlightenment. For reasons as shocking as poverty in the family, some of these children were branded witches (Snow, 2017), accused of being responsible for the sufferings in their respective families, and chased out of their home as early as five years after failed attempts to kill or maim them. Some of these children found themselves on the streets because of lack of care (Umukoro, 2016), provision of basic needs within the domestic environment (Stephen \& Udisi, 2016) and the failed quest for a better life (Lawal, 2015). Those that fall into this latter category are mostly orphans. Some of these children found themselves on the streets as a result of the breakdown of the family structure (Stephen \& Udisi, 2016) while others were chased out by their parents or wards as a result of truancy and deviant behaviour. They are usually seen in clusters around the Calabar Cultural Centre, the Cenotaph at Eleven-Eleven roundabout, Flour Mill junction, Dan Archibong Park, Bogobiri, Atekong drive among others (Kalu, 2016).

As a result of the rejection by the society, abuse, and the lack of parental care and love, these children become psychologically traumatised and end up becoming prone to negative influences on the streets (PIND, 2017). Thus, these children become ready recruits for armed robbery gangs, prostitution rings and child trafficking syndicates. They metamorphose into deadly gangs used by corrupt politicians to harass the electorates and rig results. They also constitute terror elements in tribal and religious conflicts (Owolabi, 2017). One significant attribute of these children is the exhibition of a high sense of communality as they are ever ready to defend and fend for each other from intruders and in some cases from members of other unfriendly street children. This communal feeling emerges out of their realisation that they have been betrayed and abandoned by the society. In response to this feeling, they strive so hard to hit back at the society through diverse criminal means.

For scholars and researchers in genetics and social psychology studying the development of human personality, the centrality of the debate on "nature vs nurture" is predominant. Nature vs nurture implies that human genealogy and the physical and social environment where an individual is born and raised are competing in terms of forces of development. In contrast to the past when the focus of the debate was to ascertain which of the two phenomena contributes more to personality, psychologist today agree that both nature and nurture are critical in the development of human personality.

The concept of complementarity between the desire to understand human commonalities and at the same time seek to account for individual differences is apt, because of the difficulty in understanding our 
Alakwe et al.., Adv. J Social Sci.; Vol. 3 Issue 1, pp: 23-33, 2018

differences without appreciating our common characteristics. This has led personality psychologist to seek for answers to salient questions on human personality: why do we differ from each other? In what ways do individuals differ from each other? Moreover, to what extent are these differences exhibited? According to Tucker-Drob \& Briley (2017), the answers to these questions are not straightforward.

More importantly and in the context of the challenges of street children in Nigerian cities, this paper seeks to deconstruct the role nature and nurture plays in the development of individual personalities of these street children and goes further to examine the centrality of communication in this developmental process. Methodologically, this paper adopts a mix of review of extant literature and theories of personality and communication, comments and observations of the activities of children as they strive to survive on the streets.

\subsection{Conceptualizing Personality}

Personality is described as "an individual's specific way of thinking, emotion, and behaviour, together with the psychological makeup that drives those patterns" (Funder, 1997, pp. 1-2). The way information is received and processed in a given environment that corresponds to that which occurs in other cultures can be the foundation for differences in individual personality (Triandis \& Suh, 2002). Conceptually, personality can be seen as a mix of emotions, habits, and cognition, which are activated when events and occurrences stimulate their expression. The socio-genomic model of personality (Roberts, 2017) defines personality as an enduring, automatic pattern of behaviours, feelings and thoughts exhibited by an individual at specific times (Luo, Derringer, Briley, \& Roberts, 2017). Usually, personality is unique to an individual, and even though there is some form of stability over time, personality, by definition, is not rigid or unchangeable, but retains the capacity to change over time in response to factors both internal and external to the human person.

Personality is responsible for an individual's unique adjustment to the environment. For instance, a vital feature of the authoritarian personality is total submission to authorities and being aggressive to those who exhibit characteristics different from the conventional. Interestingly, the Russians who are high on this trait reject laissez-faire individualism, whereas Americans who are high on this trait support this type of individualism (McFarland, Ageyev, \& Abalakina-Paap, 1992). Rejection of individualism is consistent with Russian conventionalism, whereas support for individualism is consistent with American conventionalism (Triandis \& Suh, 2002). Since all humans belong to the same species, and since personality is rooted in the genes, it follows that there exist more areas of convergence than divergence when we consider the personalities within cultural groups. Consequently, most researchers in the field of personality focus more on the similarities in personality across cultural boundaries.

\subsection{Factors that Affect Personality}

Several factors have been identified as exerting significant influence on the formation of human personality. Principal among these are biological (heredity), cultural, family, life experiences, and socialisation.

\subsubsection{Heredity}

Biologically, the genes play a significant role in determining individual traits in our physical attributes and behaviour. Our heights, health status, skin colour, weight, the texture of hair, are all characteristics that can be traced to heredity. Our approach to others and these inherited traits reserve the potential of influencing our personality.

\subsubsection{Culture}

Culture exerts a strong influence in shaping our personality. Individuals born and raised within a specific cultural background tend to exhibit traits that mirror such cultures. Nigeria being a multicultural society with strong diversity presents an excellent opportunity to understudy this phenomenon. 


\subsubsection{Family Background}

The type of family (monogamous or polygamous), the number of children, social and economic status, educational background of the parents and general demographics of individual families influence the shaping of personality to a large extent. From birth, the personality of the child is affected by the values of the parents as they expect total conformity to such values. This is achieved through role modelling, diverse re-enforcement strategies such as rewards and punishments. In most cases, childhood experiences differ between the first born and the rest of the children within the family.

\subsubsection{Experiences in Life}

Our level of trust for others, generosity, and self-esteem have a healthy relationship to past experiences. In most cases, our attitudes mirror our past experiences. As the saying goes, "one who has been bitten by a snake will run at the sight of an earthworm." This affirms that certain personality traits are formed by either positive or negative experiences that frequently occurs in life

\subsubsection{Socialization}

The saying that 'birds of the same feather flocks together' hold true when we consider the effect of socialisation on human personality. This means that throughout life, human beings are continually persuading each other and tends to associate more with those whose values, norms and way of life are attuned to theirs. During the formative years in the family, individuals are influenced by people they interact with. Primarily, these include parents, siblings, aunts, and uncles and later to friends, schoolmates, and colleagues. These relationships with others shape human personality. Our desire for belongingness will compel us to imbibe specific group characteristics, which subsequently mould our personality.

\section{Behaviourism and the Philosophy of Personality}

At variance with the "structuralist" philosophical basis of introspection, behaviourism emerged from a contending "functionalist" philosophy of psychology as advocated by John Dewey and William James. Based on the "structuralist" view that experience should be reified, Dewey opined that sensations be depicted as functional and proposed to treat them as functionally defined occupants of roles in the "reflex arc" (Dewey, 1896, p. 357). Behaviourism is based on the concept that humans are born tabula rasa upon which experiences accumulate over time and shape human behaviour. Behaviourism relates to those aspects of human behaviour that is capable of being observed and consequently, measured. It emphasises shifts in behaviour emanating from stimulus-response relationships made by the individual (Parkay \& Hass, 2000). Since only observable behaviour is worthy of study, behaviourists assert that it is the actions, and not emotions or thought that ought to be the legitimate object of study.

If all humans are born tabula rasa, then it can be argued that the behaviour of the Skolombo Boys result from habits imbibed over time and driven by the harsh environment of street life. Behaviourism, therefore, seeks to unravel how these habits are incubated. If they assume that human behaviour is learned, then it means that behaviours can also be erased through the introduction of new behaviour. A critical part of the theory of behaviour change is the reward-response: the expected behaviour is rewarded so that learning could be made more comfortable (Parkay\& Hass, 2000). The implication is that if that which these children need is given to them, there is the likelihood that their behaviour can be modified. Watson and Skinner are instrumental to the development of the behaviourist perspective to learning. Watson believed that human development results from observable behaviour. He developed the stimulus-response model, which posits that specific stimuli elicit an observable reaction in human behaviour. The innate desire to survive is a very compelling force that shapes these children's personalities. That is why they would steal, engage in armed robbery, prostitution or even form a ready pool of resources for militants and religious extremists. Skinner developed his operant conditioning model based on Watson's stimulus-response model. According to Skinner, those things we desire almost always have a strengthening effect on peoples' behaviour (Skinner, 1987). 


\subsection{Theoretical Framework on Human Personality}

In his book titled, "Mind, Self and Society," Mead (1934) posited that the individual 'mind' and 'self are consequences of the social process and that human experience should be viewed from the standpoint of communication which is critical in achieving social order. He introduced the concept of "conversation of gestures" using the dogfight as an example. The basic assumption of this theory is that every human act communicates, and human behaviour is simply a response to the communication or action of others. This is what he referred to as the "conversation of gestures," where communication occurs without the communicator being aware of the response to his actions and thus cannot respond to those reactions. In communication via gestures, participants communicate without knowing they are communicating. The process, therefore, is unconscious. According to Mead (1938), " the relationship between the individual and the environment" is represented by the "act."

The "act" emerges from four different but interconnected developmental stages. The first stage is impulse characterised by an individual's response to problematic situations experienced. This stage is followed by perception where the individual defines and analyses the problem and then there is manipulation, where the individual acts based on his perceptual appraisal of the challenging situation. The final stage is consummation. This stage is characterised by the resolution of the problematic situation encountered initially resulting in the re-establishment of continuity (Mead, 1938).

Mead's theory explains the unconscious effect of the society on Skolombo Boys. The rejection experienced by these children, according to Mead's position, constitutes communication and their responses in the form of robbery, begging, prostitution all reflect their reaction to societal communication. This means that an individual is not just a passive recipient of messages or environmental influences, but can act in response to these influences. Action, therefore, is constructed through the process of selective perception.

Scholars have also theorised on the role of communication in human cognitive behaviour and personality. According to Bandura's (1977), Social Learning Theory, people learn new behaviours through observation and modelling. The core assumptions of the theory are that positive rewards have a vicarious effect on observers and thus can instigate them to emulate similar attributes. This is the reason why punishing someone whom the society holds in high esteem for being involved in an undesirable act will dissuade an observer from carrying out the same action. Modelling can facilitate the acquisition of new forms of behaviour and strengthen or weaken existing ones. Social learning theory explains human behaviour from the continuous reciprocal interaction between environmental, behavioural and cognitive influences. This is referred to as reciprocal determinism. Factors that facilitate efficient modelling include Attention, Retention, Reproduction, and Motivation.

Psychological theories of human development focus on the development of capabilities, which occur mostly during the formative years of childhood characterised by rapid changes (Bandura, 1989). However, knowledge of the extent of these developments does not, on its own, give more insight into the path individual life will take. Contrary to common belief, neonates exhibit a high level of modelling capabilities. Within some months after birth, newborns can exhibit modelling with some degree of consistency (Meltzoff \& Moore, 1983). This feature is grounded on social reciprocation. Infants are born with fundamental capacities and sensorimotor coordination that gives them the ability to imitate elementary sounds and acts within their physical capabilities. From the onset, parents are quick to mimic a baby's gesture and sound in expressive ways that have been proven to facilitate modelling.

For a baby with limited social and communication means, reciprocal imitation is readily an efficient way to achieve parental responsiveness. Such acts between parents and babies serve as a way to convey interests and share experiences. This starts with the parents modelling acts performed by the infant, and once this is established, parents initiate a new pattern of response for imitative sequences which helps in expanding the baby's competencies. The ability to model these intricate patterns of behaviour requires the development of observational learning. These positions negate the view that genes are the primary determinants of 
Communication and the Shaping of Human Personality

behaviour and affirm that life experiences and socialisation through communication play a more critical role in human personality.

\subsection{Deconstructing the Role of Genes in Human Personality}

'According to Baker (2004), the difference in behavioural attributes across a given population is partly due to heredity. Some studies have focused on unravelling the connections between genes and specific behavioural traits such that researchers now make bold to say that such a relationship genuinely exist. The challenge with this position is that it implies there are genes responsible for simple acts like blushing when we feel embarrassed or even genes that dictate our taste for a specific music genre. Moreover, this is not so. Conversely, it can be assumed that personality is passed down through generations same way as we inherit skin colour. Again, the answer is no. The view that genes play a significant role in human personality is held by Weinschenk \& Dawes (2017) in their study of the relationship between genes, personality traits, and political interest which affirmed that genetic factors account for substantial correlation between personality traits and interest in politics.

The pervasive influence of the human gene on behaviour does not indicate that a single or several genes can make us react in a specific way to an external stimulus or that behaviour can be inherited. Such claims are frowned upon in behavioural research. However, what it indicates is that genes play a critical role in the development and physiology of the human body and that behaviour manifests when the body reacts to stimuli from the immediate environment. Thus, while genes are inherited, behavioural traits are not, in that sense. The outward expression of a given set of genes in terms of behaviour is, therefore, dependent upon our physical and social environment as we live on a day-to-day basis. Consequently, to say that genes predict behaviour might not be entirely correct. This is because the relationship between the human genomes and behaviour is quite complicated, circuitous and highly unclear. Their influence is contingent upon activities within and outside the body, which includes diet and socialisation. Genes have little predictive power at the level of the individual, and they do not override other specific factors that influence behaviour. These are the controversial positions that exist in the field of behavioural genetics. Scholars argue about the appropriateness of research methods, disagree with findings and question whether the benefit of such research outweighs the drawbacks.

\subsection{The Environment, Socialisation, and the Development of Personality}

Thoughts, behaviours and feelings fluctuate over time in response to environmental stimuli and lived experiences (Tucker-Drob, 2017). While not discounting the influence of genes in human personality, proponents of the nurture theory believe that such positions do not matter. Their view is that behavioural traits emanates from environmental factors and most importantly, through the process of socialisation defined as the experience garnered throughout life and which facilitates human potential and help individuals learn the culture. According to Tucker-Drob (2017), in cases where experiences are discrete, isolated and short-lived, personality traits revert to pre-existing conditions. However, the opposite is the case when situational experiences are recurrent, chronic and consistent over a more extended period. In such cases, changes in personality traits are more profound, more embedded and last much longer.

Studies on infant and child temperament have supported some very crucial element of nurture theories. Watson and Rayner (1920) demonstrated empirically that the acquisition of phobias could be explained away by classical conditioning. This position was supported by early experiments by Skinner, which proved that human behaviour could be conditioned much the same way as those of animals (Skinner, 1974). A study in new scientist suggests that having a good sense of humour is a trait without any known link to heredity but instead learned through family and cultural influences. Deckers et al. (2015), also confirmed that socio-economic status is a critical predictor of many facets of the personality of a child. According to Josefsson et al. (2013), parental care and family environment are significant predictors of child personality. From the preceding, it is evident that the environment plays a crucial role in determining human traits and 
behaviour and if this was not to be so, then, theoretically speaking, identical twins will be the same in every respect even if they grow up in the different social environment.

The critical issue, therefore, is to ascertain if human behaviour is ingrained in the genes or whether it develops over the years in response to external stimuli inherent in the environment. Individual differences often arise, persist over time and may eventually dissipate through a complex system of internal and contextual influences that interplay with each other over time (Tucker-Drob \& Briley, 2017). Researchers on all sides of nature/nurture divide, however, agree that the linkage between a gene and a specific behaviour cannot be equated with cause and effect. While a gene may indicate likely behaviour, it cannot enforce such behaviour. This means that individuals through the process of social integration still choose how to behave as they grow up. The family as a social institution and the community where a child lives influence the development of personality, especially in the Nigerian rural setting where a child is raised by the community. While some parents guide their children to uphold traditions, others emphasise religion as a principal factor in child development and personality (Mpaata, 2017). However, weak parents encourage their wards to leverage on self-monitoring behaviours in controlling their actions. According to Mpaata (2017), such children evolve to using the conscious self as a central part of their personality development which often leads to deviant behaviours such as smoking, drug abuse, irresponsibility, pornography and many others.

Related to the above is the harsh economic environment in Nigeria, especially with the recent recession, which has contributed significantly to an increase in the poverty levels. This is affirmed by Bocar (2015) where a more significant proportion of children are driven to the streets by poverty. Related to the toxic economic environment is the high cost of education and inadequate educational policies that deny these children the opportunity to acquire the most basic education. However, rather than blame the hunger and poverty to the inefficiencies of the government, indigent citizens look elsewhere for the causal factors and are quick to blame witches and wizards within and outside their family circles for their woes. Thus, children are sometimes branded as evil. Some local churches, in their bid to have maximum control on their worshippers, also prophecy impending doom if the accused children are not sent out of the family.

Another contributory factor that pushes children to the streets is migration (Ozbas, 2015). In some cases, the parents of these street children were compelled to migrate to a different society and lacking the necessary funds, resort to begging to survive. The resultant effect is, therefore, an increase in the number of street children who have been abandoned to survive or die on the streets. Some preachers go further by directing their worshippers not to assist such children in any form as such can attract negative "spiritual" powers in their families. All these contribute in communicating total rejection of these children by the society. Moreover, as expected, the feedback from these children is in the form of violence against the society which they blame for their situation.

\section{Discussion}

\subsection{Human Personality: The Nature-Nurture Debate}

The nature versus nurture debate is hinged on the influence of an individual's natural physiological makeup as opposed to forces exerted by the environment where one is reared in relation to differences in character and personality. The belief that humans acquire all their personality traits as they grow is known as tabula rasa (blank slate). The emergence of molecular evidence has been insightful to psychologists, psychiatrists, and neuroscientists in understanding the extent to which human behaviour is driven by the genes as against the environment where they live. The perceived lack of substantial evidence has further fueled this debate. The desire to proffer answers to questions on how genes and the environment interact to determine happiness or how environmental factors like therapy can facilitate the alleviation of disorders still exists. This has made the concept of separating nature from nurture a very tedious one as both are closely knitted in obliquity. 
Communication and the Shaping of Human Personality

A fundamental assumption is that the focus on the nature-nurture debate is a comparative analysis of the contributions of genes and the environment to the development of personality traits. The cyclical nature of this relationship has succeeded in recasting the debate in its entirety. Hence, we no longer speak of nature versus nurture, but rather nature via nurture. This implies that genes evolve by taking their cues from the environment.

\subsection{The Centrality of Communications in Personality Development}

Effective communication is inadvertently a significant factor in engaging individuals in relation to personal and group culture and their worldviews. Dialogism, which represents a discussion between two persons, is a multi-layered process that is continuously evolving. It aligns with the theory of "heteroglossia," defined as "the co-existence of numerous voices (polyglossia) that intersect and inter-animate one another in a single language" (Bakhtin, 1981, pp. 291-292). This means that for each socio-ideological standpoint, there is a specific worldview with its meanings, objects, and values with the capacity to interact with ideologies of others. Thus, "heteroglossia" results from the dialogical interaction between two different worldviews or voices (Bakhtin, 1981). It is expected that if the interaction between these worldviews become mutual and reciprocal, there will be mutual conditioning. This process produces change through the creative elaboration of new and differing meanings.

Every human utterance is laced with an objective often entangled in thoughts, values, point-of-view, and ideas directed at the object of the speech. This elicits a response which could either be in agreement or at variance with expectation. Every culture or society is made up of individuals with different attributes and possessing unique worldviews. However, not every utterance is taken into consideration. Personal interpretation of voices taken into accommodative interaction can provide intimate glimpses into social relations between cultural or religious groups in a multi-cultural and pluralistic society like Nigeria.

The process of socialisation is wholly ingrained in communication. This is because the force that binds societies together is dependent on communication. Without the ability to communicate, human beings will live an isolated life and cannot thus share their experiences, emotions, concerns, and knowledge. Communication, therefore, facilitates the exchange of ideas, information and encourages understanding among individuals in the society. It can also lead to challenges, disillusionment, and deviant behaviour. The unconscious, nonverbal communication emanating from the society has either a positive or negative effect on individuals. People's reaction, therefore, depends on their perception of the messages and prevailing circumstance. The media through public communication, the implementation of informal and non-formal education, entertainment and consequently socialisation also plays a critical role in the development of personality among the street children (Bradea \& Blandul, 2015). Furthermore, presenting nature as the critical driver of personality has racists and eugenic undertones. This is because, in the past, heredity has been offered as an excuse for different forms of discrimination along ethnic lines.

Communication has been said to be a 'conditio sine qua non' of human life and social order (Watzlawick, Barelas, \& Jackson, 2011). From the beginning of our existence, we are not only refining our neurophysiological capacities to communicate; we are equally engaged in the process of acquiring the social rules of communication. Historically, what we know about life comes from the study of communication as a one-way phenomenon. In relation to Abraham Maslow's' hierarchy of needs, the behaviour and personality of street children are clearly in response to the lack of that basic human need, the innate desire for survival and subsequent blame of their situation on external influences inherent in the larger society. Rejected by their family and the society, the only option left for these children is to roam the streets in search of food and shelter. Moreover, if the behaviour is learned, it can also be unlearned through conditioning. There have been cases of successful rehabilitation of these children through the provision of life's basic needs. These go to lay credence to the fact that nurture is indeed a critical factor in the formation of human personality. In the case of the Skolombo Boys, rejection by the society communicates strongly such that these children perceive the society as antagonistic to their welfare. In extreme cases, they evolve to become sociopaths and seek ways to get back at the society. Instinctively attuned to survival, these 
children will do anything to survive the next day, and as they bond together in groups, their personality evolves to become similar. This similarity results from socialisation with other children on the streets and not because they share the same genetic makeup. Thus, children from different family background are seen converging as a group on the streets and evolving to share the same personality characterised by abuse, violence, and crime.

A clear understanding of the personality of street children will offer clues on how these children will react and feel under different conditions and in a variety of situations (Mpaata, 2017). The personality of street children confirms that sensory information received by the brain does have effects on human behaviour. These street children live like animals on the streets, and for them, survival is of the fittest. The more profound they descend into hopelessness, the more the society rejects them. The feeling of rejection is usually driven by nonverbal cues from the society as exemplified by facial expressions and mannerisms exhibited by individuals as they come in contact with these street children. These non-verbals further reinforces their belief that society has abandoned them to their fate. In most cases, even governments plans and efforts for their rehabilitation is met with intense suspicion.

The human memory has a lot to do with our knowledge of the world and our actions. It is possible for us to construct memory out of the interactions of previous experiences and incoming current information (Schacter, 1990). Communication is at the core of human life and occupies a central position in shaping human behaviour. The assumption is that facial expression (nonverbal) contributes about $55 \%$ of total human communication, 38\% through paralanguage while just 7\% is via spoken words (Parmar, 2013). Human personality, therefore, is determined by the pattern and style of our communication. As we communicate, our inner attitude and feelings are continuously being reflected. Communication, therefore, is a medium which reflects one's personality. One's attitude, behavioural traits, and personality can be expressed or appraised via necessary communication skills.

\section{Conclusion}

This paper, through a review of extant literature and theories of personality argues that a group of children that aggregates on the streets may not likely share the same genetic component. Instead, the aggregation can be attributed to their response to a standard "message" from the society - rejection. The society through verbal and non-verbal means communicate rejection to these street children and thus facilitate the emergence of deviant behaviour and crime. That these children adopt violence in response to their rejection lays credence to the cyclical nature of communications since such violence perpetrated by these children can be seen as a reliable form of feedback to the society. This fact reaffirms the centrality of communication in personality development. The ability to communicate clearly and articulate views facilitate the development of personality. This ability is the point of divergence between man and animals. Thus, human personality is attributable, in no small extent, on socialisation which across all cultures is driven by communication. From the preceding, it is apt to lay the responsibility for this menace squarely on communication. The argument, therefore, is that if life on the streets is as a result of communication, then these children can be redeemed through empathy, understanding and re-socialisation leveraging on communication. The society, while having the capacity to create these street children can also stimulate behaviour change by communicating love and care. In consideration of the challenges posed by street children in the society and the urgent need to take these children off the streets, this paper recommends:

- A robust communication strategy focused on communicating love and thus stimulate behaviour modification amongst the street children.

- An awareness program is also very critical to let parents and guardian realise that children deserve love and care and that what they become in the future is greatly influenced by the treatment given to them in their formative years.

- There is also an urgent need to re-tool the education law and school curriculum to address the challenges of school drop out and make it possible for indigent families to send their wards to school. 
- $\quad$ Finally, strategies and programs must be instituted to facilitate social inclusion and the rehabilitation of street children, especially the members of the Skolombo group of Calabar.

\section{How to Cite this Article}

Alakwe, K., \& Ogbu, S. (2018, April 30). Communication and the Shaping of Human Personality; Deconstructing the Nature/Nurture Debate in Light of the Menace of Street Children in Nigeria. Advanced Journal of Social Science, 3(1), 23-33. https://doi.org/10.21467/ajss.3.1.23-33

\section{References}

Akpan, A. (2015, October 10). Skolombo, the story of Calabar street children. The Guardian. Retrieved February 11, 2018, from https://guardian.ng/sunday-magazine/skolombo-the-story-of-calabar-street-children/

Baker, C. (2004). Behavioural genetics: An introduction to how genes and environments interact through development to shape differences in mood, personality, and intelligence. New York: American Association for the Advancement of Science and Policy Programs. Retrieved July 11, 2017, from https://www.aaas.org/sites/default/files/Intro.pdf

Bakhtin, M. M. (1981). The dialogic imagination. (C. Emerson, \& M. Holquist, Trans.) Austin: University of Texas Press. Retrieved September $13, \quad 2016, \quad$ from https://warwick.ac.uk/fac/arts/english/currentstudents/undergraduate/modules/fulllist/special/english19thcentnovel/week_2__bakhtin_-_discourse_in_the_novel_1981.pdf

Bandura, A. (1971). Social learning theory. Englewood Cliffs, NJ: Prentice-Hall. Retrieved August 02, 2016, from http://www.asecib.ase.ro/mps/Bandura_SocialLearningTheory.pdf

Bandura, A. (1989). Social cognitive theory. In R. Vasta (Ed.), Annals of child development (Vol. 6, pp. 1-60). Greenwich, CT: JAI Press. Retrieved August 28, 2016, from https://www.uky.edu/ eushe2/Bandura/Bandura1989ACD.pdf

BBC. (2017, July 25). Nigeria has 'largest number of children out-of-school' in the world. Retrieved from http://www.bbc.com: http://www.bbc.com/news/world-africa-40715305

Bocar, A. C. (2015). Children on the street: Reasons of their existence and their commonly observed effects. International Journal of Social Science and Humanity, 5(7), 617-622. Retrieved March 26, 2018, from http://www.ijssh.org/papers/528-B1018.pdf

Bradea, A., \& Blandul, V. C. (2015, May 14-16). The impact of mass-media upon personality development of pupils from primary school.

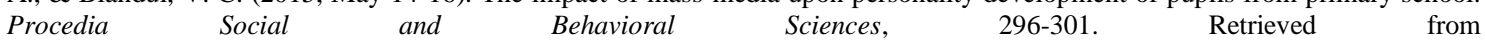
https://www.researchgate.net/publication/283956698_The_Impact_of_Massmedia_upon_Personality_Development_of_Pupils_from_Primary_School

Deckers, T., Falk, A., Kosse, F., \& Schildberg-Horisch, H. (2015). How does socio-economic status shape a child's personality? Bonn: IZA (The Institute for the Study of Labor). Retrieved April 02, 2018, from http://conference.iza.org/conference_files/Gender_2017/6591.pdf

Dewey, J. (1896). The reflex arc concept in Psychology. Psychological Review, 3, 357-370. Retrieved February 02, 2016, from https://pdfs.semanticscholar.org/a7ab/dafa9cca3547d8f441ee9dc3b5ad19ee7f59.pdf

Funder, D. (1997). The personality puzzle (6th ed.). New York: Norton. Retrieved December 30, 2017, from https://www.scribd.com/document/339522795/The-Personality-Puzzle-by-David-Funder-6th-Edition-pdf

Gungea, M., Jaunky, V. C., \& Ramesh, V. (2017). Personality traits and juvenile delinquency: A critical analysis. International Journal of Conceptions on Management and Social Sciences, 5(1), 42-46. Retrieved March 25, 2018, from https://www.researchgate.net/publication/314151962_Personality_Traits_and_Juvenile_Delinquency_A_critical_analysis

Ibanga, I. (2016, March 4). Untold story of how Skolombo street children terrorise Calabar residents. Premium Times. Retrieved March 2, 2017, from https://www.premiumtimesng.com/investigationspecial-reports/199249-investigation-untold-story-of-how-skolombostreet-children-terrorise-calabar-residents.html

Josefsson, K., Jokela, M., Hintsanen, M., Cloninger, C. R., Pulkki-Raback, L., Merjonen, P., . . Keltikangas-Jarvinen, L. (2013). Parental care-giving and home environment predicting offspring's temperament and character traits after 18 years. Psychiatry Research, 209(3), 643-651. doi:10.1016/j.psychres.2013.01.007

Kalu, N. (2016, April 16). Skolombo boys terrorise Cross River. The Nation. Retrieved March 21, 2018, from http://thenationonlineng.net/skolombo-boys-terrorise-cross-river/

Lawal, F. (2015, 05 23). The Skolombo storm: Meet the street urchins taking over Cross River. Pulse. Retrieved April 03, 2018, from http://www.pulse.ng/gist/the-skolombo-storm-meet-the-street-urchins-taking-over-cross-rivers-id3790081.html

Luo, J., Derringer, J., Briley, D. A., \& Roberts, B. W. (2017). Genetic and environmental pathways underlying personality traits and perceived stress: Concurrent and longitudinal twin studies. European Journal of Personality, 31, 614-629. doi:10.1002/per.2127

McFarland, S., Ageyev, V., \& Abalakina-Paap, M. (1992). Authoritarianism in the former Soviet Union. Journal of Personality and Social Psychology, 63, 1004-1010. Retrieved from http://www.psych.utoronto.ca/users/peterson/psy430s2001/McFarland\%20SG\%20Authoritarianism\%20in\%20Soviet\%20Union\%2 0JPSP\%201992.pdf

Mead, G. H. (1934). Mind, self and society from the standpoint of a social behaviorist. (C. W. Morris, Ed.) Chicago: University of Chicago. $\begin{array}{llll}\text { Retrieved } & \text { April } & \text { 2016, } & \text { from }\end{array}$ https://campus.fsu.edu/bbcswebdav/institution/academic/social_sciences/sociology/Reading\%20Lists/Social\%20Psych\%20Prelim\% 20Readings/I.\%20Classics/1934\%20Mead\%20-\%20The\%20Self.pdf

Mead, G. H. (1938). The philosophy of the act. (C. W. Morris, J. M. Brewster, A. M. Dunham, \& D. Miller, Eds.) Chicago: University of Chicago Press. Retrieved from https://brocku.ca/MeadProject/Mead/pubs2/philact/Mead_1938_28.html

Meltzoff, A. N., \& Moore, M. K. (1983). The origins of imitation in infancy: Paradigm, phenomena, and theories. In L. P. Lipsitt, \& C. K. Rovee-Collier (Eds.), Advances in infancy research (Vol. 2, pp. 266-301). Norwood, NJ: Ablex Publishing. Retrieved from https://www.researchgate.net/publication/232510772_The_origins_of_imitation_in_infancy_Paradigm_phenomena_and_theories

Mpaata, A. K. (2017). Youth personality development and the ultimate character: The neglected role of educators. International Journal of Youth Economy, 1(1), 105-118. doi:http://dx.doi.org/10.18576/ijye/010107

Owolabi, E. F. (2017). Street children as threat to national security and peace in Nigeria: Can the Child Rights Act serve as a panacea? KIU Journal of Social Sciences, 3(2), 91-99. Retrieved April 10, 2018, from www.ijhumas.com/ojs/index.php/kiujoss/article/download/15/14 
Alakwe et al.., Adv. J Social Sci.; Vol. 3 Issue 1, pp: 23-33, 2018

Ozbas, M. (2015). Personal and familial properties of street children. Journal of Education and Learning, 4(1), 97-107. Retrieved from https://files.eric.ed.gov/fulltext/EJ1075167.pdf

Parkay, F. W., \& Hass, G. (2000). Curriculum planning: A contemporary approach. Boston: Allyn and Bacon. Retrieved April 22, 2017, from http://youkof.club/go/read.php?id=0205307108

Parmar, P. (2013). Role of communication in the Improvement of one's personality. Language in India, 13(6), 699-704. Retrieved from http://languageinindia.com/june2013/prabhapersonalitycommunication.pdf

PIND. (2017). The street kids of Calabar: A punitive approach is not enough. Abuja: Partnership Initiative in the Niger Delta. Retrieved March 24, 2018, from http://library.fundforpeace.org/library/briefing-the-street-kids-of-calabar.pdf

Plomin, R., \& Petrill, S. A. (1997). Genetics and intelligence: What's new? Intelligence, 24, 53-77. Retrieved from https://www.sciencedirect.com/science/article/pii/S0160289697900131

Roberts, B. W. (2017). A revised sociogenomic model of personality traits. Journal of Personality. doi:https://doi.org/10.1111/jopy.12323

Schacter, D. L. (1990). Perceptual representation systems and implicit memory: Towards a resolution of the multiple memory systems debate. In A. Diamond (Ed.), The development and neural bases of higher cognitive function (pp. 543-571). New York: Annals of the New York Academy of Science. Retrieved April 04, 2018, from https://pdfs.semanticscholar.org/27f2/3ec49cf404e0346b6c8917462d048b906fdf.pdf

Shamaki, E. B. (2016). The role of education as a tool for social integration of street children in Jalingo Local Government Area of Taraba State, Nigeria. International Journal of Innovative Psychology \& Social Development, 4(1), 11-16. Retrieved April 09, 2018, from seahipaj.org/journals-ci/mar-2016/IJIPSD/full/IJIPSD-M-2-2016.pdf

Skinner, B. F. (1974). About behaviorism. New York: Knopf. Retrieved June 18, 2015, from http://fitelson.org/prosem/skinner_2.pdf

Skinner, B. F. (1987). Skinner on Behaviourism. In R. L. Gregory (Ed.), The Oxford companion to the mind. New York: Oxford University Press. Retrieved April 07, 2018, http://dlx.bok.org/genesis/436000/5b13dca9709280117a1988021587ee75/_as/[O._L._Zangwill,_R._L._Gregory]_The_Oxford_Compani(bok.xyz).pdf

Snow, S. (2017). Explaining the abuse of "Child Witches" in Africa. Journal of Religion and Society, 19, 1-21. Retrieved from https://dspace2.creighton.edu/xmlui/bitstream/handle/10504/114375/2017-29.pdf

Stephen, E. N., \& Udisi, L. (2016). Street children in Akwa Ibom state, Nigeria: Br beyond economic reason. Cross-Cultural Communication, 12(10), 19-28. doi:http://dx.doi.org/10.3968/8926

Triandis, H. C., \& Suh, E. M. (2002). Cultural influences on personality. Annual Review of Psychology, 53, 133-160. Retrieved from https://www.annualreviews.org/doi/abs/10.1146/annurev.psych.53.100901.135200?journalCode=psych

Tucker-Drob, E. M. (2017). How do individual experiences aggregate to shape personality development? Austin: Department of Psychology and Population Research Center. Retrieved from https://labs.la.utexas.edu/tucker-drob/files/2015/02/Tucker-Drob-EJP-How-DoIndividual-Experiences-Aggregate-to-Shape-Personality-Development.pdf

Tucker-Drob, E. M., \& Briley, D. A. (2017). Theoretical concepts in the genetics of personality development. In D. P. McAdams, R. L. Shiner, \& J. L. Tackett (Eds.), Handbook of personality development. Retrieved from https://pdfs.semanticscholar.org/8691/eb8be5c7b7ee2f75cb1ecc6843b8245d3c25.pdf

Umukoro, A. (2016, May 1). Skolombo epidemic: How Calabar children labelled witches turn into street gangsters. The Punch. Retrieved April 07, 2018, from http://punchng.com/skolombo-epidemic-calabar-children-labelled-witches-turn-street-gangsters/

UNICEF. (2005). The state of the world's children. Oxford University Press. Retrieved April 03, 2018, from https://www.unicef.org/sowc/archive/ENGLISH/The\%20State\%20of\%20the\%20World\%27s\%20Children\%202005.pdf

UNICEF. (2015). Humanitarian action for children. Retrieved February 25, 2018, from https://www.unicef.org: https://www.unicef.org/appeals/files/Final_2015_HAC_Nigeria_chapter.pdf

Usang, E. E., Okpechi, P. A., \& Ekpo, E. B. (2016). The taxonomy of street children and their effect on the society. International Journal of Social Science and Humanities Research, 4(1), 116-122. Retrieved March 25, 2018, from http://www.researchpublish.com/journal/IJSSHR/Issue-1-January-2016-March-2016/60

Watson, J. B., \& Rayner, R. (1920). Conditioned emotional reactions. Journal of Experimental Psychology, 3(1), 1-14. Retrieved from https://www.birdvilleschools.net/cms/lib/TX01000797/Centricity/Domain/1013/AP\%20Psychology/Little\%20Albert\%20Article.pdf

Watzlawick, P., Barelas, J. B., \& Jackson, D. D. (2011). Pragmatics of human communication: A study of interactional patterns, pathologies, and paradoxes. New York: W. W. Norton \& Company. Retrieved July 10, 2016, from http://b-ok.xyz/book/2544908/f32141

Weinschenk, A. C., \& Dawes, C. T. (2017). The relationship between genes, personality traits and political interest. Political Research Quaterly, 70(3), 467-479. doi:10.1177/1065912917698045

Zuriff, G. E. (1985). Behaviorism: A conceptual reconstruction. New York: Columbia University Press. Retrieved November 27, 2017, from http://booksc.org/book/39239597/850e93

Publish your research article in AIJR journals-

$\checkmark$ Online Submission and Tracking

$\checkmark$ Peer-Reviewed

$\checkmark$ Rapid decision

$\checkmark$ Immediate Publication after acceptance

$\checkmark$ Articles freely available online

$\checkmark \quad$ Retain full copyright of your article.

Submit your article at journals.aijr.in
Publish your books with AIJR publisher-

$\checkmark$ Publish with ISBN and DOI.

$\checkmark$ Publish Thesis/Dissertation as Monograph.

$\checkmark$ Publish Book Monograph.

$\checkmark$ Publish Edited Volume/ Book.

$\checkmark$ Publish Conference Proceedings

$\checkmark \quad$ Retain full copyright of your books.

Submit your manuscript at books.aijr.org 